\title{
HIGHLIGHTS OF SEVERAL WORKS ON METAPHYSICS AND TASAWWUF
}

\author{
Oleh: \\ Metsra Wirman* \\ Lecturer of Philosophy at Department of Islamic Education, Faculty of Islamic \\ Religion, Universitas Muhammadiyah Sumatera Barat (UMSB) Padang \\ corresponding author: metsrawirmanalidin@ gmail.com
}

\begin{abstract}
This article is a summary of the important points in the subject of philosophy of science, especially, Metaphysics idea or in Islamic sense. It calls as "Tasawwuf" (Islamic metaphysics). From several works, for instance, Immanuel Kant's Prolegomena to Any Future Metaphysics, S.M.N alAttas's Islam and the Philosophy of Science, and Nür al-Dīn alRānirī's Latā'if al-Asrār li Ahli Allah al-Atyār. From these three books, here is the highlight in order to understand their views on Metaphysics and Tasawwuf. The survey aims to analyze and compare their views, particularly on pertaining on Metaphysics. The study was found that Metaphysics, deals in general with questions about the nature of reality. The Sufis took the same position as the philosophers and the theologians in affirming the reality of thing that constitute the world, and hence also the reality of the world, as established, in contradiction to the Sophists. But the Sufis attested further, in significant contrast to the philosophers and the theologians, that in addition to existence in the above sense, that is, as a pure concept, and based upon clear mystical revelation and true intuition founded upon the authority of the Holy Qur'an and the tradition as well as upon reason and experience.
\end{abstract}

Keywords: Epistemology, Metaphysics, Philosophy of Science, Reality, Sufism (Tasawwuf), Truth.

\section{A. Introduction}

In nearly every branch of philosophy, the Islamic tradition is rich beyond belief, if only its sources were made known. This is especially true of metaphysics. Islamic metaphysics should be presented as what it is, that is, the science of Ultimate Reality, which is the one (al-Ahad) or Allah, who has revealed Himself in the Quran, and not as a 
discredited branch of rationalistic philosophy. Metaphysics is generally accepted as a branch of philosophy, concerned with the nature of ultimate reality. In the Islamic sense, metaphysics which includes of course its original concern, theology, is the most important because it influences the Muslim conception of the universe, human psychology, epistemology, ethics and even logic.

\section{B. Metaphysics}

The Greek term Metaphysics is translated into Arabic as "Mā $b a$ 'da al-Tabī'ah" which literally means, "what comes after (beyond) physics". it is also called as alilāhiyāt (Divinity) and al-falsafah alÛlā (the first philosophy) in the same manner as Moslem Philosophers like al-Kindi, Ibn Sinā, and al-Farābī (Fakhry, 1982).

The term "metaphysics" was first used to refer to a group of treatises written by Aristotle. Historians of philosophy tell us that the term represents the Greek phrase "ta meta ta physica", which means the books next after the Physics. This phrase was not used by Aristotle himself but by ancient editors as a title for a group of treatises placed after the Physics in an early collection of Aristotle's works. Aristotle called the subject he was concerned with in his metaphysics "first philosophy", a subject that had gradually taken shape in the work of his predecessors-specifically, so called Pre-Socratic's, Socrates, and Plato (Aune, 1998).

The book discusses the mode of being or existence, pertaining to reality which is not independent of human reason and refers to aspects of reality that is immaterial or nonphysical, like God and human intellect. In the philosophy of science, we can distinguish between epistemological issues and metaphysical issues. Epistemology is concerned with questions about knowledge, evidence, and rationality. Metaphysics, deals in general with questions about the nature of reality (Godfrey-Smith, 2003). In fact, according Ibn 'Arab̄̄ in his Futūhāt ${ }^{1}$ (Rosenthal, 2007), metaphysics is considered to be the highest knowledge.

In Islam, Metaphysics is generally accepted as a branch of philosophy which is concerned with the nature of ultimate reality. Metaphysics is the most important discipline because it determines the Moslem conception of the universe, human psychology, epistemology, ethics and even logic. We realized that metaphysics is no longer popular in modern science discourse. This attitude, which is western, is neither morally honest nor rationally justifiable because literal meaning of the term does include all the major components of what philosophy of

1. The four large areas of knowledge are logic, mathematics, physics and metaphysics. Metaphysics is the highest knowledge of them all. All the other kinds of knowledge are subordinated to it. As reported by Franz Rosenthal, Knowledge Triumphant the concept of knowledge in medieval Islam (Leiden: Brill, 2007), 187, also in Ibn 'Arabī's book Cf. Futūhāt, I , 293 
education (as such) considers pertinent.

\section{Tasawwuf or Sufism (Metaphysics of Islam)}

Sufism or tasawwuf, according to al-Attas, is defined as "the practice of Shariah at the station (maqam) of ihsān (Al-Attas, 1993). By ihsān, he meant the highest stage of religion, above and inclusive of those of Islam and Iman, as conveyed by the famous hadith narrated by 'Umar Ibn al-Khattab and transmitted by Abu Hurayrah and Muslim, in which the Prophet said of ihsan "that you should worship God as if you saw Him"...(an ta'buda Allah ka annaka tarāhu) (Al-Attas, 1981).

In the concluding paragraph of his commentary on the Hujjat alSiddīq of Nūr al-Dīn al-Rānirī, alAttas states that Islamic metaphysics, which is for him the philosophical Sufism, is a unified system that discloses the ultimate nature of Reality in positive terms; for it integrates reason and Experience with other higher orders in the suprarational and transempirical level of human consciousness.

He asserts that "...no formulation of a philosophy of education and a philosophy of science along Islamic lines can be developed by ignoring the great contributions of the Sufi masters on the ultimate nature of reality." Moreover, he added, "intellectual Sufism can effect a reconciliation between Muslim theology and philosophy just as it has achieved a great measure of understanding and unity between Sunnism and Sh'ism (Wan Daud, 1998).

In Islam, Metaphysics is generally accepted as a branch of philosophy which is concerned with the nature of ultimate reality. Metaphysics is the most important discipline because it determines the Moslem conception of the universe, human psychology, epistemology, ethics and even logic. We realized that metaphysics is no longer popular in modern science discourse. This attitude, which is western, is neither morally honest nor rationally justifiable because literal meaning of the term does include all the major components of what philosophy of education (as such) considers pertinent.

D. Summary of Metaphysics aspect in Immanuel Kant, Syed Muhammad Naquib Al-Attas and Muhammad Zainiy Uthman's work.

In the book, Prolegomena to Any Future Metaphysics by Immanuel Kant (Kant, 1977) is a scientific work, which deals with the concept of philosophy pertaining how man can arrived at knowledge, based on his rationality. Kant's emphasized on the fundamental elements of science, whereas he introduced the limits of reason and the inability of human mind to know the ultimate reality of the object to be observed.

Kant tries to examine the pure philosophical cognition, what he calls it as a priori, whereas man possesses a knowledge about thing without deriving it from his experiences, for instance, the mathematic discipline 
and physical science (Kant, 1977). Based on this conception, he examines the possibility of pure mathematics and pure natural science as the prerequisite for man to gain knowledge and make judgment upon the nature that he experienced.

He focus on to investigate the ability of the human reason, whether it has an ability to know the reality of the thing being perceived, or it observed with the fastened perceptions - like as the concept of space and time. He discusses further about the possibility of metaphysics, that he proposes his standpoint that metaphysical knowledge is only attained through the pure reason, not from sensible experiences, since the real metaphysical object is unattainable. Then he concludes with the determination of the limits of pure reason in his Prolegomena. The object of metaphysics, like as God and soul, are impossible to be known and not as they are.

At the end of his work, Kant tries to save the possibility of metaphysics as a science. $\mathrm{He}$ proposes that man can only developed in this knowledge without illusionary and dialectical arguments (Kant, 1977) by investigating how can he knows metaphysical knowledge through experiences and relates it with his understanding in his "the critique of pure reason's book. In this book, Kant tries to explains how can the human mind made a conception out of the sensual observation of the natural world, by introducing the abilities and limits of reason to understand the reality of the observed nature.
At the very end, Kant can ask the final question, whether a science of metaphysics is possible. The answer to this is negative since we can have no experience of these metaphysical entities. They are merely products, indescribable, of pure reason itself. Metaphysics, then, rests in a very uncomfortable place after Kant has dealt with it. Souls, physical reality, and God have only a very slight and rather insignificant possibility as abstract "finishing concepts" whose entire meaning comes out of the phenomenal world that we experience.

In the book of Islam and the Philosophy of Science by Prof. Syed Naquib Al-Attas, there are some important similities found between our position and that of modern, contemporary philosophy and science with regard to the sources and methods of knowledge; the unity of the rational and emphirical ways of knowing; the combination of realism, idealism, and pragmatism as the cognitive foundation of a philosophy; the philosophy and science of process. But these similities are apparent and pertain only to their external aspects, and they do not negate the profound differences that arise from our divergent worldviews and belief about the ultimate nature of Reality. Our affirmation of Revelation as the source of knowledge of ultimate reality and truth pertaining both to created things as well as to their Creator provides us with the foundation for a metaphysical framework in which to elaborate our philosophy of science as an integrated system descriptive of that reality and truth in a way which 
is not open to the methods of the secular philosophic rationalism and philosophic empiricism of modern philosophy and science (Al-Attas, 1989).

In Islamic senses, a metaphysical science rooted in the intellect and revelation, in addition to a philosophy of nature based upon it could provide both criticism and evaluation of scientific discoveries and hypotheses. The two would be complementary in as much as the modern sciences deal with detailed knowledge and metaphysics with the ultimate knowledge of things. At the same time metaphysics, being independent of science, could examine its presuppositions and act as its independent critic and judge ${ }^{2}$.

The metaphysics of Islam as understood by Prof. Syed Muhammad Naquib al-Attas is a synthesis of ideas and theories that have been traditionally upheld by

2. In a sense, metaphysics and science are complementary. Metaphysics does not deal with the detailed behavior of nature; science does not deal with the ultimate interpretation of natural knowledge. They are both necessary to a synthetic view of the world. But the relation is one-side; science cannot begin without assuming a metaphysical principle, whereas metaphysics does not presuppose any scientific principle for the validity of its conclusions. One of the functions of metaphysics is to examine the grounds for presuppositions of science, just as one function of logic is to lay bare these presuppositions. But this does not exhaust metaphysics...'.
Muslim theologians (mutakallimūn), philosophers (Hukamā' and Sufis (ahl al-Tasawwuf)). The elements and elaborations of this metaphysics are found scattered in his definitive commentaries on the two of the greatest scholars of the Malay world, Hamzah Fansuri (fl. circa. 15501600) (Al-Attas, 1970).

According to al-Attas rightly point out, pertaining the metaphysics of Islam :

"Our affirmation of
revelation as the source of
knowledge of ultimate
reality and truth
pertaining both to created
things as well as to their
Creator provides us with
the foundation for
metaphysical framework
in which to elaborate our
philosophy of science as
an integrated system
descriptive of that reality
and truth in a way which
is not open to the methods
of the secular philosophic
rationalism and
philosophic empiricism of
modern philosophy and
science.

In the book of Latā' if al-Asrār li ahl Allah atyār of Nur al-Dīn alRānirī (Uthman, 1997) is a work to clarify and to eludicate the right from the wrong interpretation of Sufi doctrines. This work is devoted to clarifying the fine and subtle aspects of spiritual mysteries or secret bestowed upon the Sufis at their attainment of illuminative knowledge (ma'rifah) of God and their experience of unification (tawhìd) as 
they scale the different spiritual stations (maqāmāt) and states (aḥwāl).

The Idea of Metaphysics in Raniri's works is deals with ontology in briefly, and thus establishes the basis for his discussion on illuminative knowledge of God and affirmation of His Unity. Al-AlRānirī draws a clear relation between certainty, unification and illuminative knowledge, and the spiritual states by quoting Shaykh Raslan al-Dimashqi who commented on the saying by shaykh Junayd:

Certainty (yaqin) is that
you abandon your
endeavour (upayamu),
your power (kuasamu) and
your (subjective) existence
(wujudmu) such that you
see (pandang) only His
overwhelming sway
(upaya-Nya), His power
(quwwatNya), and His
existence (WujudNya) over
your weakness (lemahmu)
and insufficiency
(da'ifmu); then per chance,
you will pass away (fana')
from your subjective
consciousness and your
certainty (yaqin) of the
unicity (wahdaniyyah) of
God Most Exalted will
increase manifold. This is
the rank of the Veracious
(Șiddiqin) (Uthman, 1997).

Al-Rānirī proceeds to elucidate on illuminative knowledge, Ma'rifah. He begins with a statement,

3 . i.e. subjective consciousness.

4 . Affirmation of Divine Unity based on the saying of the holy Prophet, that God has made a reqirement upon sentient beings, namely the Jinns and Humankind, to know Him (Ma'rifah) because to know God is a requirement of religion $(d \bar{l} n)$. Hence, knowledge of God (ma'rifah) consists of proper recognition and acknowledgement of Him which will, in turn, lead to willing submission (Islam) (Uthman, 1997).

That existence is real is instantiated by existent things (mawjudāt), or creation in general, and they, in turn, point to the reality of their Creator. Creation is originated and things originated are imbued with potentialities. What is potential derives its potentiality from something actual; hence the existence of originated things is dependent on existence which in itself is actual existence - that which is truly and really existing. God's existence is an actuality which is not preceded by potentiality, hence, His existence is necessary (wajjib), and selfsubsisting.

Hence, Raniri's affirmation of the existence of God. Ibn 'Arabi makes the same statement concerning the method adopted by the Sufis in regard to the reality of existence. In his letter to Muhammad al-Razi, he says that the method of affirmation (ithbāt) is the method of the Sufis while the method of negation (Salb) is the method of the philosophers. He says, "intellects (come to) know God with respect to His Existence as existing ( $\min$ haythu kawnuhu mawjudan) by negation (Salb) not by way of affirmation (lā min haythu ithbāt) (Uthman, 1997). The Sufis, 
while not denying the validity of the method of negation, admit of another method in attaining to the knowledge of the Truth Most Exalted, namely contemplation (mushāhadah) and spiritual witnessing (mua'yanah) of God's revelation (kashf). To be sure the two methods of arriving at the knowledge of God lead to two kinds of knowledge of God: one that is intellectually arrived at which can be considered as theological formulation of who God is based on proof of tradition, whereas the second is illuminative, the kind that bestowed upon by way gift from God. In order to receive illuminative knowledge (ma'rifah) through spiritual experience, according Ibn 'Arabi, it is necessary for the intelligent man (al'Áqil) to empty his heart (an yakhla qalbahu) from deliberation (al-Fikr).

Knowledge of God (al-' Ilm bi-Allah), says Ibn 'Arabi, as obtained by spiritual witnessing (Mushāhadah). By Mushāhadah, the Sufis mean, to "actually know by direct experience and vision (shuhūd) the Reality and the Truth that is revealed to them (Al-Attas, 1986)". The philosophers (hukamā') and the theologians (mutakallimun) view existence $(W u j \bar{u} d)$ as an accident ('âriḍ) which inheres in the Subtrata (ma'rudāt) of quiddities (mahiyyāt) and realities (haq $\left.\bar{a}^{\prime} i q\right)$. Since it is in their opinion that existence is an accident to quidity, absolute existence, meaning that existence which encompasses all (i.e. general existence), is only a construction of the mind, a concept. It exist only in the mind (wujūd dhihni) but not externally (wujūd khārijī). Contrary to this position which considers existence as a mere concept, the Sufis are of the view that existence is a reality. The reality of existence is the very substratum (ma'rud) in which accidents inhere and whatever that we perceive as individuals existing extramentaly are but existent thing that came into manifestation because of that Reality of Existence which goes through the process of individuation (ta'ayyun) and determination (taqayyud), manisfesting itself in manisfestation forms (sing, mazhar).

\section{E. Conclusion}

Metaphysics, deals in general with questions about the nature of reality. The Sufis took the same position as the philosophers and the theologians in affirming the reality of thing that constitute the world, and hence also the reality of the world, as established, in contradiction to the Sophists. But the Sufis attested further, in significant contrast to the philosophers and the theologians, that in addition to existence in the above sense, that is, as a pure concept, and based upon clear mystical revelation and true intuition founded upon the authority of the Holy Qur'an and the tradition as well as upon reason and experience.

Metaphysics would distinguish carefully distinguish between facts assembled diligently by scientist and hypotheses, many unproven, which are used to integrate these facts into some meaningful pattern. A total and complete science of things would be able to judge these hypotheses and their implications. It would stand as standard with respect to which modern science would be 
compared and judged. Metaphysical intuition can occur anywhere but the effective realization of metaphysical truth and its application to human life can only be achieved within a

\section{References}

Al-Attas, S. M. N. 1970. The Mysticism of Hamzah Fansuri. Kuala Lumpur: University of Malaya Press.

\begin{tabular}{|c|c|}
\hline Positive & $\begin{array}{rr}1981 . & \text { The } \\
\text { Aspects } & \text { of }\end{array}$ \\
\hline Tasawwuf, & Preliminary \\
\hline Thoughts & on an Islamic \\
\hline Philosophy c & of Science. Kuala \\
\hline $\begin{array}{l}\text { Lumpur: Isla } \\
\text { Science (AS }\end{array}$ & $\begin{array}{l}\text { lamic Academy of } \\
\text { SASI). }\end{array}$ \\
\hline
\end{tabular}

1986.

A

Commentary on the Hujjat alSiddīq of Nūr al-Dīn alRānirī. Kuala Lumpur: International Institute of Islamic Thought and Civilization (ISTAC). 1989. Islam and The Philosophy of Science. Kuala Lumpur: International Institute of Islamic Thought and Civilization (ISTAC).

1993. Islam and

Secularism. Kuala Lumpur:

International Institute of Islamic Thought and Civilization (ISTAC).

Aune, B. 1998. Metaphysics the Elements (Fourth Printing). revealed tradition which gives efficacy to certain symbols and rites upon which metaphysics must rely for its realization. Wallahu a 'lam

London: University of Minnesota Press.

Fakhry, M. 1982. The Subject Matter of Metaphysics: Aristotle and Ibn Sina (Editor Michael E. Marmura). New York: State University of New York Press.

Godfrey-Smith, P. 2003. Theory and Reality: an Introduction to The Philosophy of Science. Chicago: University of Chicago Press.

Kant, I. 1977. Prolegomena to Any Future Metaphysics (revised by James W. Ellington). Indiana: Hackett Publishing Company.

Uthman, M. Z. 1997. Lațā' if al-Asrārr li Ahl Allah Atyār (Dissertation for the Degree of Doctoral Philosophy at International Institute of Islamic Thought and Civilization) - ISTAC). Kuala Lumpur.

Wan Daud, M. N. 1998. The Educational Philosophy and Practice of Syed Muhammad Naquib Al-Attas. Kuala Lumpur: ISTAC. 